\title{
Nutritional issues for women in developing countries
}

\author{
BY SUSAN P. WALKER
}

Tropical Metabolism Research Unit, University of the West Indies, Mona, Kingston 7, Jamaica

The topic of nutrition of women in developing countries has largely been equivalent to maternal nutrition with emphasis on the effect of the mother's nutritional status on birth weight and lactational performance. Little attention has been paid to the well-being of the mother and the effects of nutrition on her performance in social and economic activities. In the present review I will limit discussion of maternal nutrition to its relationship with the nutritional status of the mother as opposed to the child, and will focus on other aspects of women's nutrition. Issues related to reproduction are the topic of another review in the present symposium (Goldberg, 1997).

Recognition of the importance of nutrition of women in developing countries has increased over the past decade with initiatives by a number of international organizations helping to encourage work in this area. The United Nations Administrative Committee on Coordination/Sub-Committee on Nutrition (ACC/SCN) held a symposium in 1989 on Women and Nutrition (Administrative Committee on Coordination/Sub-Committee on Nutrition, 1990) which considered issues such as women's work loads and time constraints. The International Center for Research on Women together with the US Agency for International Development co-ordinated a research programme, involving twenty projects in developing countries, on Maternal Nutrition and Health Care from 1987-90 (Parker et al. 1990). Although this second initiative focused on maternal nutrition, the emphasis was on the mother's nutritional status rather than pregnancy outcomes. The United Nations International Children's Emergency Fund dealt with the topic of women's work and the need for access to child care (Himes et al. 1992) and launched the Girl Child Initiative to address issues related to gender discrimination in childhood. These programmes mark a needed broadening of the area of women's nutrition to finally move away from equating it with maternal nutrition.

\section{DEVELOPING COUNTRIES}

Developing countries form a diverse group with varied economic and socio-cultural conditions. They range from the so-called least-developed countries to the rapidlydeveloping economies in east Asia and encompass market economies through highlycentralized ones. Per capita gross national product (GNP) varies from as little as $\$ 100$ in countries in Africa such as Mozambique, Tanzania and Ethiopia to over $\$ 2000$ in some Latin American (e.g. Costa Rica, Brazil) and Asian (e.g. Malaysia, Thailand) countries (United Nations International Children's Emergency Fund, 1996). Differences in basic infrastructure and the priority given to expenditure on health, education and welfare result in discrepancies between GNP and the health and nutrition status of the population. The contrasting examples of Sri Lanka and Libya are shown in Table 1. Socio-cultural factors, particularly as they relate to the position of women in society, are also important in determining the nutrition of women.

Some developing countries are experiencing an epidemiological transition, with a change from infectious diseases and undernutrition to chronic diseases such as hypertension and diabetes as the most important cause of morbidity and mortality. 
Table 1. Gross national product (GNP) and health and education indicators in Sri Lanka and Libya (From United Nations International Children's Emergency Fund, 1996)

\begin{tabular}{lcc}
\hline \hline & Sri Lanka & Libya \\
\hline GNP (USS) & 600 & 5310 \\
Under 5 years mortality rate (deaths/1000 live births) & 19 & 95 \\
Life expectancy at birth (years) & 72 & 63 \\
Female literacy (\%) & 85 & 54 \\
\hline
\end{tabular}

Further, within-country variations between rural and urban areas and among social classes will affect the nutritional issues of most relevance to women. The main issues for moreaffluent women in these countries or for the majority of women in countries in transition are probably similar to those of women in developed countries. These will be discussed by the other speakers at the present symposium and will not be addressed here.

\section{CHILDHOOD UNDERNUTRITION}

Protein-energy malnutrition remains prevalent in many developing countries (de Onis et al. 1993). The most common form of undernutrition is stunting or low height-for-age. The percentage of children less than 5 years of age who are stunted $(<-2$ SD of World Health Organization/National Center for Health Statistics reference values; Hamill et al. 1977) is illustrated in Fig. 1 for selected developing countries. Childhood undernutrition has important long-term functional consequences for work capacity (Haas et al. 1995) and mental development (Gorman, 1995; Grantham-McGregor, 1995). In addition, short stature in women is associated with small pelvises and increased risk of obstructed labour, which is reported to occur in 2-14\% of deliveries in developing countries and in Bangladesh is the cause of 10-17\% of maternal deaths (Royston \& Armstrong, 1989). Risk of obstructed labour rises sharply in women less than $1.45 \mathrm{~m}$ tall and is also greater in women $1.5 \mathrm{~m}$ tall compared with those $1.6 \mathrm{~m}$ or taller. Approximately 16-18\% of women in Asia have heights below $1.45 \mathrm{~m}, 11-15 \%$ of women in Latin America, and $3 \%$ of women in Africa. Average heights are 1.57-1.58 m in Africa, 1.52-1.54 m in Latin America and 1.50-1.51 m in Asia. For comparison average height in Europe is $1.61 \mathrm{~m}$ with almost no women with heights below $1.45 \mathrm{~m}$ (Administrative Committee on Coordination/Sub-committee on Nutrition, 1992).

\section{Gender discrimination}

Preference for sons is evident in several developing countries. Expressed preference (mothers who would prefer their next child to be a boy : those preferring a girl) is high in South Asia and the Middle East, while moderate preference for sons is typical in Africa and other Asian countries. In most Latin American countries there is equal preference, while in only two (Venezuela and Jamaica) of the thirty-eight countries reviewed was there a slight preference for girls (Ravindran, 1986). Expressed preference does not necessarily translate into discrimination in health care or nutrition, although there is evidence for this in a number of countries, particularly in South Asia.

Gender discrimination in relation to nutrition can take the form of less food or food of lower quality being given to girls than boys, girls may be breast-fed for shorter periods (Chatterjee \& Lambert, 1990) and mothers may become pregnant again sooner after a 


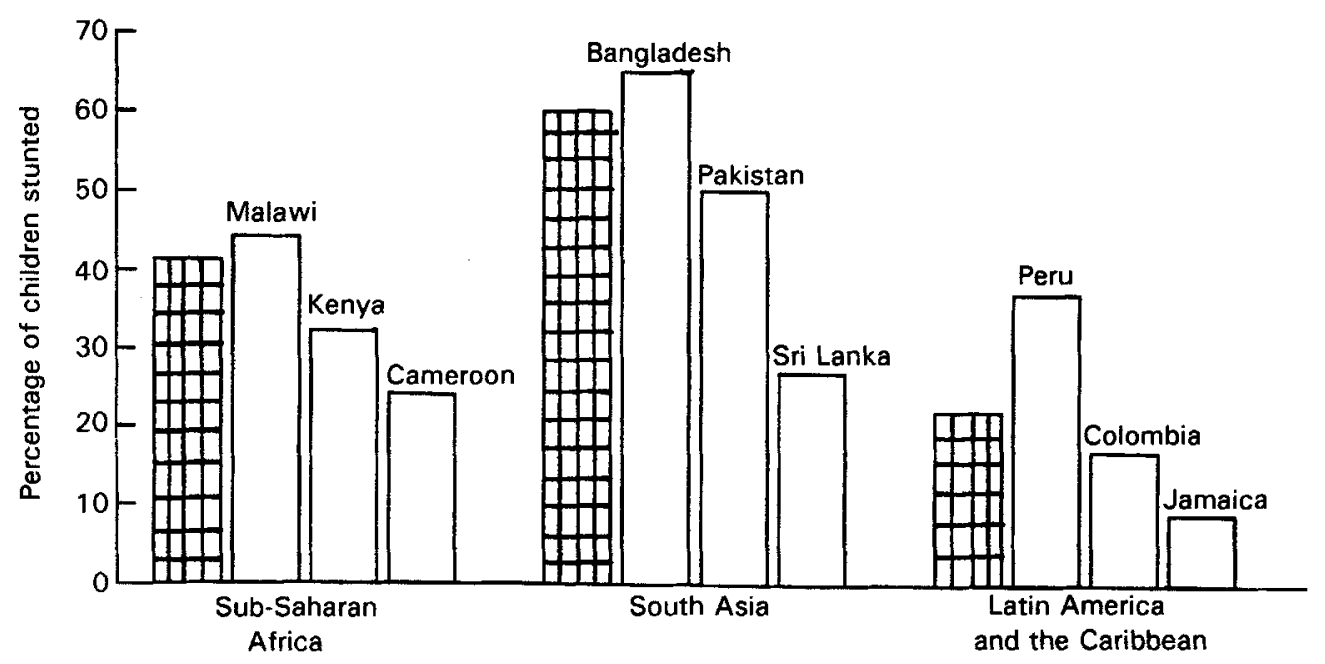

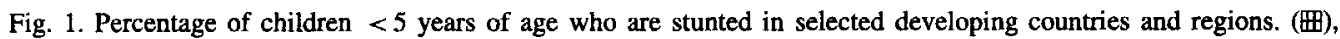
Regional average. (Data taken from de Onis et al. 1993).

daughter and stop breast-feeding when they become pregnant (Khan, cited in Royston \& Armstrong, 1989). Patterns of intra-household food distribution are discussed later in relation to women, but there is evidence that in some countries girls receive less food than boys from age 1-4 years (Carloni, 1981; Abdullah \& Wheeler, 1985). Several studies in South Asia have shown girls to have poorer nutritional status than boys (Chen et al. 1981; Bairagi, 1983; Sabir \& Ebrahim, 1984; Bajaj, 1989), although this is not always seen (Martorell et al. 1984). The data from Sabir \& Ebrahim (1984) is illustrated as an example in Fig. 2. Differences in childhood nutritional status by gender are seen less frequently in Africa. Where differences have been seen (Tripp, 1981; Mbago \& Namfua, 1992) they are thought to be due to the cultural practice of boys eating with their fathers and, thereby, having access to more and better food and there was little evidence of active discrimination against girls.

Parents may also be more likely to seek health care, or seek care sooner, for sons than daughters. There is some evidence for this from a study in India where the ratio of malnutrition in girls compared with boys was $4: 3$ in the community but more boys than girls were brought to hospital (Gopalan \& Naidu, 1972). This pattern was also seen in Pakistan where the prevalence of illness was the same in boys and girls but more boys were taken to a doctor (Sabir \& Ebrahim, 1984). The combination of poorer nutritional status and less access to health care probably leads to the higher mortality rates from 1 to 4 years of age seen among girls in Pakistan and India and in some countries in Africa (Kholsa, 1980; World Bank, 1994).

\section{REPRODUCTIVE HEALTH}

The maternal mortality rate shows the greatest difference between developed and developing countries of any public health indicator (Royston \& Armstrong, 1989). The rates are highest in sub-Saharan Africa where they range from 230 to 1100 maternal deaths per 100000 births (United Nations International Children's Emergency Fund, 1996). 


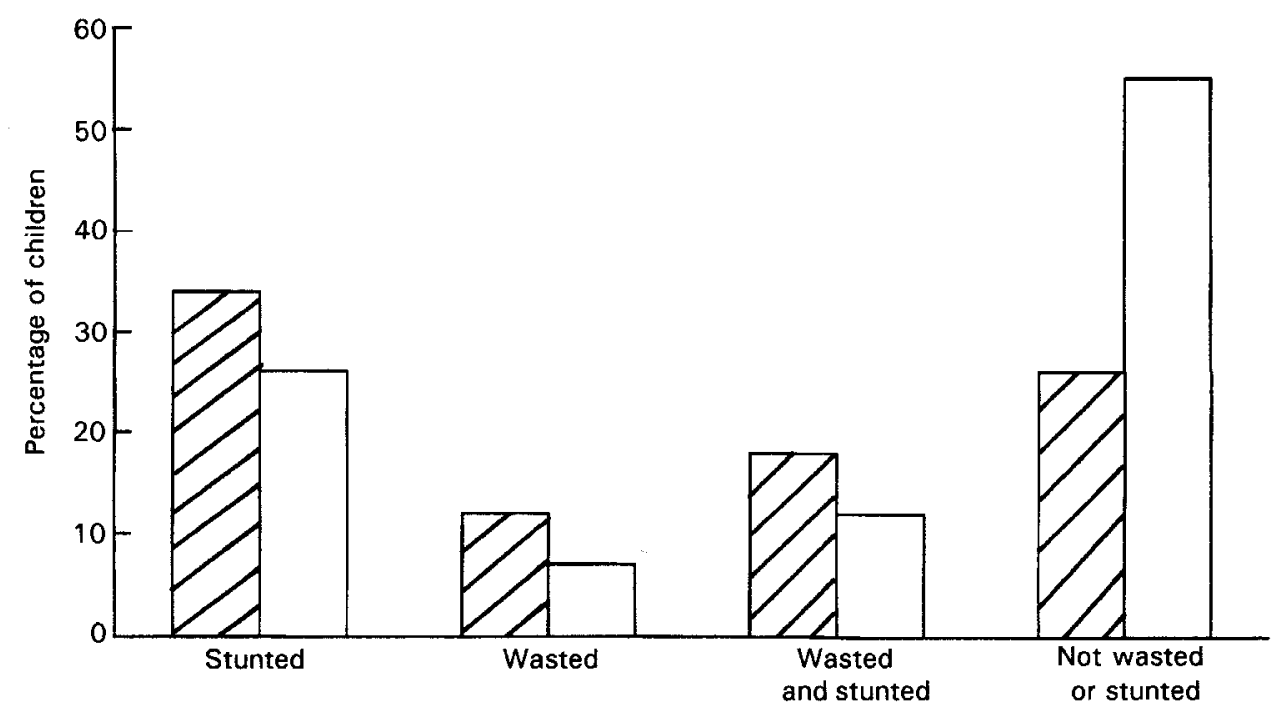

Fig. 2. Percentage of boys $(\square)$ and girls $(\square)$ aged $<5$ years in Lahore, Pakistan who are stunted, wasted, both stunted and wasted or normal. (Data taken from Sabir \& Ebrahim, 1984.)

Maternal mortality rates are also high in most other developing regions, for example South Asia (80-600 deaths/100 000) and in Latin America and the Caribbean (40-600 deaths/ 100000 ). In comparison maternal mortality rates are less than 20/100 000 in Europe. Although much of this difference can be explained by inadequacies in health care, maternal nutritional characteristics such as short stature or anaemia increase a woman's risk of complications at birth and of mortality.

The average number of births to women in developing countries ranges from four to eight. When the amount of time spent breast-feeding is added to this a large proportion of Third World women's reproductive years are spent under the increased nutritional demands of either pregnancy or lactation. McGuire \& Popkin (1990) have estimated that from age 15 to 45 years the amount of time women are pregnant or breast-feeding ranges from $23 \%$ in Costa Rica to $61 \%$ in Bangladesh, with a typical range for Asian and African women of $35-48 \%$.

Frequent reproductive cycles, particularly among women whose nutritional intakes are marginal, are likely to contribute to deterioration in the mother's nutritional status. For example, the weight-for-height of non-pregnant, non-lactating (NPNL) women in Bangladesh was lower in women with higher parity (Huffman et al. 1985). Short recuperative intervals between the end of lactation and the next pregnancy and overlap of lactation and pregnancy are particularly stressful and have been shown to lead to depletion of maternal body fat (Merchant et al. 1990). Short non-pregnant intervals and breastfeeding continuing into the third trimester are also associated with lower weight gains in pregnancy (Siega-Riz \& Adair, 1993). Approximately $50 \%$ of women studied in Guatemala and the Philippines experienced overlap of lactation with the subsequent pregnancy (Merchant et al. 1990; Siega-Riz \& Adair, 1993).

Although weight loss is a normal feature of the post-partum period, in nutritionallyat-risk women even moderate weight loss may have consequences for maternal health. Adair \& Popkin (1992) investigated weight loss from 2 to 24 months post-partum in Filipino women, as part of a longitudinal study of the health and nutrition of the women 
and their infants. Of the women, $55 \%$ had net weight loss over this interval, and duration of lactation, particularly lactation for more than 12 months, was a significant predictor of weight loss. Weight loss may have the most serious implications for the $14 \%$ of women in the sample who had BMI $<18.5$ at 2 months post-partum, and in $88 \%$ of these women BMI did not increase over the duration of the study. In addition, BMI decreased to $<18.5$ in $16 \%$ of women with adequate BMI at 2 months post-partum. Weight loss in women with low BMI was comparable with that of women with adequate BMI indicating that nutritionally-vulnerable women may have been further compromised.

Another factor which may contribute to maternal depletion is that there may be little reduction in activity levels by women when they are pregnant or breast-feeding, even in late pregnancy. A cross-cultural study of pre-industrial and traditional societies found that in fifty-one of $112(45 \%)$ societies women continued full duties until labour and in another twenty-seven reduced activity after the 7 th month of pregnancy (Jimenez \& Newton, 1979). Women also returned to full activity soon after birth, in ninety-eight of 195 cases within 2 weeks. In an observational study of women's activity in Malawi, Tucker \& Lamba (1990) also found little reduction in activity from mid pregnancy through to the postpartum period. However, Lawrence \& Whitehead (1988) reported a reduction in physical activity during late pregnancy and the first month of lactation in rural Gambian women.

\section{Teenage pregnancy}

Of births in developing countries $10-50 \%$ are to teenage mothers. Early child-bearing is common where teenage marriage is the norm, such as in several countries in South Asia. However, teenage pregnancy rates are also high in other regions, for example in Latin America and the Caribbean $10-25 \%$ of births are to teenage mothers and $40-66 \%$ of women have given birth by the time they are 20 years old (Pan American Health Organization, 1994).

Pregnancy during adolescence is associated with increased risk of obstetric complications and mortality (Royston \& Armstrong, 1989). In addition there may be competition for nutrients between the fetus and the growth needs of the young mother. Growth in stature continues until age 18 years and growth of the pelvis continues for 2-3 years after growth in stature is complete, through late adolescence (Moerman, 1982). Using increase in knee height as a more sensitive measure of growth during pregnancy, Scholl et al. (1990) found that $56 \%$ of adolescent girls in the USA grew during pregnancy and in those who were multiparous, maternal growth was associated with lower birth weights. There is little information on the effects of lactation on the nutritional status of adolescents. However, in one small study in India, adolescents lost more weight during the first 3 months of lactation than adult women (Geervani \& Jayashree, 1988).

\section{WORK AND ENERGY EXPENDITURE}

The heavy work load of low-income women in developing countries is well established (Leslie, 1988; McGuire \& Popkin, 1990). Time-allocation studies have been conducted in several countries and examples from different regions in the Third World are shown in Table 2. Rural women typically spend $3-4 \mathrm{~h}$ in agricultural production, $2-5 \mathrm{~h}$ in food processing and preparation and 0.5-3 h collecting fuel and water and a further $1-5 \mathrm{~h}$ in other work such as production of crafts and marketing (Leslie, 1988). The amount of time spent in child care may be difficult to determine as this often occurs concurrently with other tasks; however, where this has been recorded the time allocated to child care ranges 
Table 2. Time allocation $(h / d)$ of women in developing countries from three regions

\begin{tabular}{lccc}
\hline \hline & $\begin{array}{c}\text { Nepal } \\
\text { (Berio, 1984) }\end{array}$ & $\begin{array}{c}\text { Burkina Faso } \\
\text { (Bleiberg } \text { et al. 1980) }\end{array}$ & $\begin{array}{c}\text { Nicaragua } \\
\text { (Leslie, 1988) }\end{array}$ \\
\hline Agriculture & 3.7 & 4.6 & - \\
Collecting food and water & 1.1 & 0.7 & 0.5 \\
Food processing and cooking & 3.0 & 2.0 & 3.5 \\
Child care* & 0.7 & 0.1 & 1.0 \\
Other work $\dagger$ & 2.3 & 2.1 & 5.6 \\
Total & 10.8 & 9.5 & 10.6 \\
\hline
\end{tabular}

*Often occurs concurrently with other tasks and not recorded separately so may be underestimated.

†Includes household activities, crafts and marketing.

from $20 \mathrm{~min}$ to $3 \mathrm{~h}$. The total amount of time spent working is generally between 7 and 12 $h$. Women work longer hours than men in most countries and have less time for leisure and social activities and this differential is also seen in the work done by girls and boys (Bério, 1984; McGuire \& Popkin, 1990).

Although the amount of time spent in various activities is often reported, there is less information on the energy expenditure of women. Variations in the intensity of tasks and rest periods during the activity may limit the accuracy of calculations of energy expenditure using standard values for the energy costs of activities (World Health Organization, 1985). Bleiberg et al. (1980) measured the energy costs of women's activities in Burkina Faso and calculated their energy expenditures from the time spent in various activities to be $9.7 \mathrm{MJ}(2320 \mathrm{kcal})$ in the dry season, increasing to $12.1 \mathrm{MJ}$ $(2890 \mathrm{kcal})$ in the rainy season when more time was spent farming. Energy expenditure of Gambian women measured in early pregnancy also varied by season and on average was $10 \mathrm{MJ}$ (2400 kcal; Lawrence \& Whitehead, 1988). In contrast, in Ethiopia, total energy expenditure of rural women calculated from measured BMR and energy costs of activities was $7.9 \mathrm{MJ}$ (1899 kcal) (Ferro-Luzzi et al. 1990). This relatively low value reflects the lower activity level of the women who performed few agricultural tasks compared with women elsewhere in Africa. The physical activity level of the women in the Gambia and Burkina Faso ranged from moderate (1.68 in the Gambia) to heavy (1.97) in the dry and rainy seasons, while that of the Ethiopian women was light (1.47). Most research on energy expenditure in Third World women has focused on the energy costs of pregnancy and lactation and more information is needed on the energy expenditure of NPNL women in developing countries.

\section{Implications of time constraints for nutrition and health care}

Many primary health care strategies for maternal and child health require substantial time inputs by women. In the context of the limited free time available to many women in developing countries, failure to take their time constraints into account may affect the success of health programmes. Women are responsible for many activities related to health and nutrition, such as food preparation, child care and hygiene, and often make the initial decisions regarding use of health care. Although children are the beneficiaries, most nutrition interventions are targeted at women who are expected to access services and act on new knowledge (Leslie, 1995). McGuire \& Popkin (1990) have described the conflicts that poor women in developing countries face in trying to fulfil their economic, biological and social roles, as a zero-sum game in which increased time or energy spent in one area may have negative effects on another. They also point out that the child survival revolution 
has to be implemented by women who must, for example, take their children for immunizations and growth monitoring, and prepare and administer oral rehydration solutions. The time costs to women are not trivial (Leslie, 1988) and have been insufficiently recognized in most primary health care systems and by international agencies.

\section{DIETARY INTAKES}

The energy and protein intakes of women in selected developing countries are shown in Table 3. The samples are not representative and include rural women (Ethiopia, Kenya, Guatemala), migrant workers (Brazil) and wives of mine workers (Papua New Guinea). Energy intakes are often below recommended values and women typically meet a smaller percentage of the requirements than men. Protein intakes are usually more adequate; however, women may consume lower-quality protein than men. For example, in Burkina Faso women were reported to consume only $0.8 \mathrm{~g}$ animal protein compared with $10.3 \mathrm{~g}$ consumed by men (McGuire \& Popkin, 1990). Intakes of micronutrients such as $\mathrm{Ca}, \mathrm{Fe}$, riboflavin, niacin and retinol are also often below recommended levels (Desai et al. 1980; Ulijaszek et al. 1987; Gittelsohn, 1991).

Although there are problems associated with collection of dietary information which may lead to underestimation of intakes, the data in Table 3 suggest, given the moderate to high levels of physical activity described (see p. 350), that many poor women in developing countries are chronically energy deficient. Further evidence for this relating to $\mathrm{BMI}$ is discussed later.

\section{Intra-household food distribution}

The unequal distribution of food is an important cause of the inadequate intake of women in poor households. Lower intakes by women as a percentage of requirements have been reported in several settings (Carloni, 1981; Samarasinghe et al. 1990), particularly in South Asia. Although women are usually responsible for food preparation, they give priority to the men in the households, feeding their husbands first, then their children (sometimes boys before girls) and then themselves. Rizvi (1983) has described how this self-sacrificing role in intra-household food distribution is acquired by girls who learn to be least demanding and give priority to the male members of the household. In a detailed observational study of intra-household food allocation in Nepal, women had lower energy intakes than men, were served after men and in some age-groups received fewer second helpings (Gittelsohn, 1991). Higher-status foods, especially animal products, were also given preferentially to males.

Table 3. Energy and protein intakes of non-pregnant women in developing countries

\begin{tabular}{|c|c|c|c|c|}
\hline \multirow[b]{2}{*}{ Country } & \multirow[b]{2}{*}{ Reference } & \multicolumn{2}{|c|}{ Energy } & \multirow[b]{2}{*}{ Protein $(g)$} \\
\hline & & MJ & kcal & \\
\hline Papua New Guinea & Ulijaszek et al. (1987) & $6 \cdot 2-7 \cdot 3$ & $1491-1763$ & $27 \cdot 3-35.9$ \\
\hline Kenya & Kusin et al. (1984) & $7 \cdot 4$ & 1765 & 59.0 \\
\hline Ethiopia & Ferro-Luzzi et al. (1990) & $8 \cdot 5$ & 2023 & - \\
\hline Brazil & Desai et al. (1980) & $4 \cdot 5$ & 1068 & 28 \\
\hline Guatemala & Schutz et al. (1980) & 7.9 & 1876 & - \\
\hline
\end{tabular}


Women's role in decision making in the household may increase where they earn their own income and women's employment may thus benefit household nutrition. Although women's incomes are often lower than men's, if women have control of their income they may allocate more of it to food and health expenditures (Chatterjee \& Lambert, 1990; Holmboe-Ottesen et al. 1988, 1989). Women's income has been associated with better nutritional status of their children (Tripp, 1981) and, in some cases, higher energy intake by the women (Adair et al. 1990). However, labour force participation often reduces the time available for child care and may have a negative impact on their children's nutritional status where adequate alternate care is not available (Popkin, 1980).

\section{CHRONIC ENERGY DEFICIENCY}

A BMI of $<18.5$ has been recommended as an indicator of chronic energy deficiency in adults (James, 1994). In many developing countries substantial percentages of women have BMI below this level, reaching as high as $61 \%$ in a sample of Indian women (Ferro-Luzzi et al. 1992). However, there is wide variation and in some populations experiencing an epidemiological transition the problem is one of obesity rather than undernutrition (Fig. 3).

The functional implications of a low BMI were reviewed at a recent workshop (James \& Ralph, 1994). Women with low BMI were reported to experience greater morbidity and to have reduced activity levels (Garcia \& Kennedy, 1994; World Health Organization, 1995). Lower productivity has also been found in female factory workers with low weight and weight-for-height (Satyanarayana et al. 1978). The effects of chronic energy deficiency experienced by poor women on their health and their ability to work either in home production of food or to earn incomes probably contribute to a continued cycle of poverty.

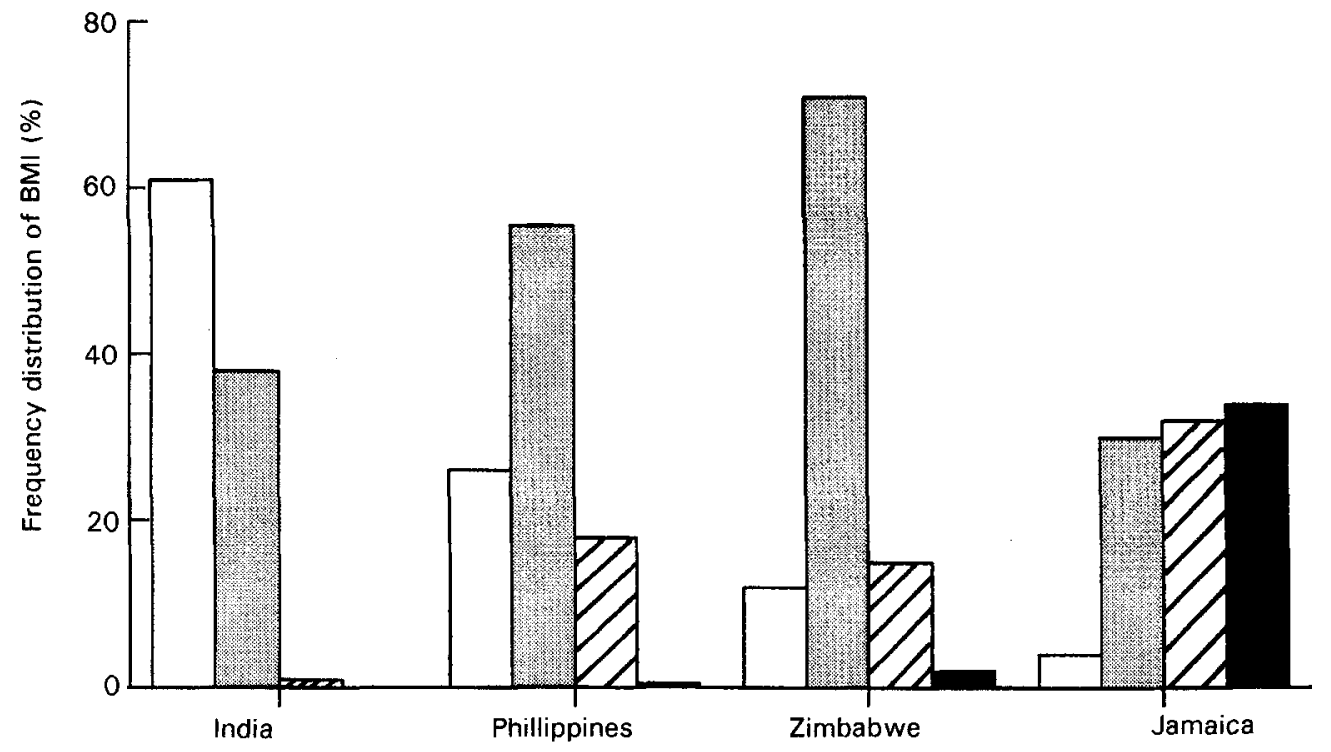

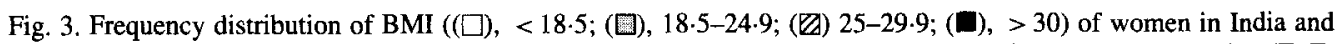
Zimbabwe (data from Ferro-Luzzi et al. 1992), Philippines (data from Garcia \& Kennedy, 1994) and Jamaica (T. E. Forrester, personal communication). 


\section{ANAEMIA}

The prevalence of anaemia, the majority of which is due to Fe deficiency, is extremely high amongst women in developing countries (Table 4; Administrative Committee on Coordination/Sub-Committee on Nutrition, 1992). Even in countries where energy deficiency is rare, anaemia remains a significant problem. For example, in Jamaica, where less than $5 \%$ of women have BMI $<18.5$ (T. E. Forrester, personal communication), the prevalence of anaemia in pregnant women is $52 \%$ and in lactating women is $42 \%$ (University of West Indies/Ministry of Health, Jamaica, 1987).

Anaemia is associated with deficits in cognitive ability (Pollitt, 1993) and work capacity. In a controlled trial of Fe treatment given to Fe-deficient female tea pickers in Sri Lanka, the quantity of tea picked increased significantly after one month of supplementation with the increase being greatest in women who were initially most anaemic (Edgerton et al. 1979). Anaemia is of particular concern in pregnancy. When severe, anaemia can be a direct cause of maternal mortality due to heart failure or infections resulting from impaired resistance. More frequently, anaemia increases the risk of death from haemorrhage (Royston \& Armstrong, 1989) which is the single largest cause of maternal death in many developing countries.

\section{OLDER WOMEN}

There is little information on the nutrition of women past reproductive age in developing countries. These women may have more status than younger women in some societies, but in others may be vulnerable, especially if widowed and dependent on male relatives. Because of their influence on younger women, older women may be important targets of nutrition intervention and education programmes. Health issues related to chronic diseases are important amongst older women in developing countries as in developed countries. In most countries in Latin America and the Caribbean, cardiovascular disease, cancer and diabetes are among the five most common causes of mortality for women in the age-groups 49-64 years and over 65 years (Sennot-Miller, 1989). However, in some countries in the region, respiratory infections and nutritional deficiencies remain important causes of death. In one community studied in Jamaica, the main health problems of women over age 65 years were hypertension, diabetes, arthritis and anaemia (Mesfin et al. 1989).

Osteoporosis is a major health problem in women in developed countries. However, there is little information on the prevalence of osteoporosis amongst women in developing countries. Chronic undernutrition, especially in childhood and adolescence, and repeated

Table 4. Prevalence (\%) of anaemia in women aged 15-49 years* (From Administrative Committee on Coordination/Sub-committee on Nutrition, 1992)

\begin{tabular}{lcc}
\hline \hline & Pregnant & Non-pregnant \\
\hline Sub-Saharan Africa & 50 & 40 \\
Near-East and North Africa & 44 & 31 \\
South Asia & 64 & 64 \\
South-East Asia & 56 & 47 \\
Middle America and Caribbean & 34 & 27 \\
& South America & 21 \\
\hline
\end{tabular}

*Anaemia is defined as haemoglobin $<110 \mathrm{~g} / \mathrm{i}$ in pregnant women, $<120 \mathrm{~g} / \mathrm{in}$ non-pregnant women. 
Table 5. Nutritional issues and underlying socio-economic factors for women in developing countries

\begin{tabular}{ll}
\hline \hline $\begin{array}{l}\text { Maternal depletion } \\
\text { including anaemia } \\
\text { Chronic energy deficiency: } \\
\text { Intra-household food distribution } \\
\text { High work loads }\end{array}$ & $\begin{array}{c}\text { Lack of ability to limit fertility (access to } \\
\text { family planning, cultural pressures) } \\
\text { Poverty, gender discrimination, lack of basic } \\
\text { technology }\end{array}$ \\
\hline
\end{tabular}

pregnancies may increase the risk of osteoporosis, whereas other factors such as high physical activity may be protective.

\section{CONCLUSIONS}

The many nutritional problems faced by women in developing countries can be grouped in three main areas: childhood undernutrition leading to short stature; frequent reproductive cycles contributing to deterioration of maternal nutritional status including anaemia; heavy work loads and expenditure which, together with marginal dietary intakes, mean that many poor women in the Third World are chronically energy deficient. The consequences of these nutritional problems can include increased risk of maternal mortality, reduced work capacity and increased morbidity due to reduced resistance to infections. Inadequate nutrition amongst women in developing countries will, therefore, often lead to impairments in the women's health and affect their ability to fulfil their social and occupational roles.

Although the focus of the present review has been on nutritional issues, these may actually be thought of as symptoms of underlying social and economic issues. A few examples of these are given in Table 5. Interventions to improve the nutrition of women are unlikely to be successful in the long term unless these issues are also addressed.

\section{REFERENCES}

Abdullah, M. \& Wheeler, E. F. (1985). Seasonal variations, and the intra-household distribution of food in a Bangladeshi village. American Journal of Clinical Nutrition 41, 1305-1313.

Adair, L. S. \& Popkin, B. M. (1992). Prolonged lactation contributes to depletion of maternal energy reserves in Filipino women. Journal of Nutrition 122, 1643-1655.

Adair, L. S., Popkin, B. M., Bisgrove, E. \& Barba, C. (1990). A Longitudinal Analysis of the Patterns and Determinants of Women's Nutrition in the Philippines. Maternal Nutrition and Health Care Program Report no. 1. Washington, DC: International Center for Research on Women.

Administrative Committee on Co-ordination/Sub-committee on Nutrition (1990). Women and Nutrition. ACC/ SCN Symposium Report. Nutrition Policy Discussion Paper no. 6. Geneva: United Nations.

Administrative Committee on Coordination/Sub-Committee on Nutrition (1992). Second Report on the World Nutrition Situation. vol. 1, Global and Regional Results. Geneva: United Nations.

Bairagi, R. (1983). Dynamics of child nutrition in rural Bangladesh. Ecology of Food and Nutrition 13, $173-178$.

Bajaj, S. (1989). The nutrition security system at the household level: Policy implications. Food and Nutrition Bulletin 11, 6-12.

Bério, A. (1984). The analysis of time allocation and activity patterns in nutrition and rural development planning. Food and Nutrition Bulletin 6, 53-68.

Bleiberg, F. M., Brun, T. A. \& Goihman, S. (1980). Duration of activities and energy expenditure of female farmers in dry and rainy seasons in Upper Volta. British Journal of Nutrition 43, 71-82.

Carloni, A. S. (1981). Sex disparities in the distribution of food within rural households. Food and Nutrition 7 , 3-12.

Chatterjee, M. \& Lambert, J. (1990). Women and nutrition: Reflections from India and Pakistan. Women and Nutrition. ACC/SCN Symposium Report Nutrition Policy Discussion Paper no. 6. Geneva: United Nations.

Chen, L. C., Huq, E. \& D'Souza, S. (1981). Sex bias in the family allocation of food and health care in rural Bangladesh. Population and Development Review 7, 55-70. 
de Onis, M., Monteiro, C., Akré, J. \& Clugston, G. (1993). The world-wide magnitude of protein-energy mainutrition: an overview from the WHO Global Database on Child Growth. Bulletin of the World Health Organization 71, 703-712.

Desai, I. D., Garcia Tavares, M. L., Dutra de Oliveira, B. S., Douglas, A., Duarte, F. A. M. \& Dutra de Oliveira, J. E. (1980). Food habits and nutritional status of agricultural migrant workers in Southern Brazil. American Journal of Clinical Nutrition 33, 702-714.

Edgerton, V. R., Gardner, G. W., Ohira, Y., Gunawardena, K. A. \& Senewiratne, B. (1979). Iron-deficiency anaemia and its effect on worker productivity and activity patterns. British Medical Journal 2, 1546-1549.

Ferro-Luzzi, A., Scaccini, C., Taffese, S., Aberra, B. \& Demeke, T. (1990). Seasonal energy deficiency in Ethiopian rural women. European Journal of Clinical Nutrition 44, Suppl. 1, 7-18.

Ferro-Luzzi, A., Sette, S., Franklin, M. \& James, W. P. T. (1992). A simplified approach of assessing adult chronic energy deficiency. European Journal of Clinical Nutrition 46, 173-186.

Garcia, M. \& Kennedy, E. (1994). Assessing the linkages between low body mass index and morbidity in adults: Evidence from four developing countries. European Journal of Clinical Nutrition 48, Suppl. 3, S90-S97.

Geervani, P. \& Jayashree, G. (1988). A study on nutritional status of adolescent and adult pregnant and lactating women and growth of their infants. Journal of Tropical Pediatrics 34, 234-237.

Gittelsohn, J. (1991). Opening the box: Intrahousehold food allocation in rural Nepal. Social Science and Medicine 33, 1141-1154.

Goldberg, G. R. (1997). Reproduction: a global nutritional challenge Proceedings of the Nutrition Society 56, 319-333.

Gopalan, C. \& Naidu, A. (1972). Nutrition and fertility. Lancet ii, 1077-1079.

Gorman, K. S. (1995). Malnutrition and cognitive development: Evidence from experimental/quasiexperimental studies among the mild-to-moderately malnourished. Journal of Nutrition 125, Suppl., 2239S-2244S.

Grantham-McGregor, S. (1995). A review of studies of the effect of severe malnutrition on mental development. Journal of Nutrition 125, Suppl., 2233S-2238S.

Haas, J. D., Martinez, E. J., Murdoch, S., Conlisk, E., Rivera, J. A. \& Martorell, R. (1995). Nutritional supplementation during the pre-school years and physical work capacity in adolescent and young adult Guatemalans. Journal of Nutrition 125, Suppl., 1078S-1089S.

Hamill, P. V., Drizd, T. A., Johnson, C. L., Reed, R. B. \& Roche, A. F. (1977). Growth Curves for Children, Birth-18 years DHEW Publication no. 78-1650. Hyattsville, MD: National Center for Health Statistics.

Himes, J. R., Landers, C. \& Leslie, J. (1992). Women, Work and Child Care. Innocenti Global Seminar: Summary Report. Florence, Italy: UNICEF.

Holmboe-Ottesen, G., Mascarenhas, O. \& Wandel, M. (1988). Women's role in food production and nutrition: Implications for their quality of life. Food and Nutrition Bulletin 10, 8-15.

Holmboe-Ottesen, G., Mascarenhas, O. \& Wandel, M. (1989). Women's role in food chain activities and the implications for nutrition. ACC/SCN State-of-the-Art Series Nutrition Policy Discussion Paper no. 4. Geneva: United Nations.

Huffman, S. L., Wolff, M. \& Lowell, S. (1985). Nutrition and fertility in Bangladesh: nutritional status of nonpregnant women. American Journal of Clinical Nutrition 42, 725-738.

James, W. P. T. (1994). Introduction: the challenge of adult chronic energy deficiency. European Journal of Clinical Nutrition 48, Suppl. 3, S1-S9.

James, W. P. T. \& Ralph, A. (editors) (1994). The functional significance of low body mass index. European Journal of Clinical Nutrition 48, Suppl. 3.

Jimenez, M. H. \& Newton, M. (1979). Activity and work during pregnancy and the post-partum period: A cross cultural study of 202 societies. American Joumal of Obstetrics and Gynecology 135, 171-179.

Kholsa, T. (1980). The plight of female infants in India. Journal of Epidemiology and Community Health 34, $143-146$.

Kusin, J. A., Van Steenbergen, W. M., Lakhani, S. A., Jansen, A. A. J. \& Renqvist, U. (1984). Food consumption in pregnancy and lactation. In Maternal and Child Health in Rural Kenya: An Epidemiological Study, pp. 127-142 [J. K. Van Ginneken and A. S. Muller, editor]. London: Croom-Helm.

Lawrence, M. \& Whitehead, R. G. (1988). Physical activity and total energy expenditure of child-bearing Gambian village women. European Journal of Clinical Nutrition 42, 145-160.

Leslie, J. (1988). Women's Time: A Factor in The Use of Child Survival Technologies? Washington, DC: International Center for Research on Women.

Leslie, J. (1995). Improving the nutrition of women in the Third World. In Child Growth and Nutrition in Developing Countries: Priorities for Action, pp. 117-138 [P. Pinstrup-Andersen, D. Pelletier and $\mathrm{H}$. Alderman, editors]. Ithaca and London: Cornell University Press.

McGuire, J. \& Popkin, B. M. (1990). Beating the zero sum game: Women and nutrition in the third world. In Women and Nutrition. ACC/SCN Symposium Report Nutrition Policy Discussion Paper no. 6. Geneva: United Nations.

Martorell, R., Leslie, J. \& Moock, P. R. (1984). Characteristics and determinants of child nutritional status in Nepal. American Journal of Clinical Nutrition 39, 74-86. 
Mbago, M. C. Y. \& Namfua, P. P. (1992). Some determinants of nutritional status of one- to four-year-old children in low income urban areas in Tanzania. Joumal of Tropical Pediatrics 38, 299-306.

Merchant, K., Martorell, R. \& Haas, J. (1990). Maternal and fetal responses to the stresses of lactation concurrent with pregnancy and of short recuperative intervals. American Journal of Clinical Nutrition $\mathbf{5 2}$, 280-288.

Mesfin, E., Sinha, D. P., Jutsum, P. J., Simmons, W. K. \& Eldemire, D. (1989). Nutritional status, socioeconomic environment, and lifestyle of the elderly in August Town, Kingston, Jamaica. Mid-Life and Older Women In Latin America and the Caribbean, pp. 211-226. Washington, DC: PAHO and American Association of Retired Persons.

Moerman, M. L. (1982). Growth of the birth canal in adolescent girls. American Journal of Obstetrics and Gynecology 143, 528-532.

Pan American Health Organization (1994). Health Conditions in the Americas, vol. 1. PAHO Scientific Publication no. 549, pp. 84-86. Washington, DC: PAHO.

Parker, L. N., Gupta, G. R., Kurz, K. M. \& Merchant, K. M. (1990). Better Health for Women: Research Results from the Maternal Nutrition and Health Care Program. Washington, DC: International Center for Research on Women.

Pollitt, E. (1993). Iron deficiency and cognitive function. Annual Review of Nutrition 13, 521-537.

Popkin, B. M. (1980). Time allocation of the mother and child nutrition. Ecology of Food and Nutrition 9, 1-14.

Ravindran, S. (1986). Health Implications of Sex Discrimination in Childhood: A Review Paper and an Annotated Bibliography. Geneva: WHO.

Rizvi, N. (1983). Effects of food policy on intra-household food distribution in Bangladesh. Food and Nutrition Bulletin 5, 30-34.

Royston, E. \& Armstong, S. (editors) (1989). In Preventing Maternal Deaths. Geneva: WHO.

Sabir, N. I. \& Ebrahim, G. J. (1984). Are daughters more at risk than sons in some societies? Journal of Tropical Pediatrics 30, 237-239.

Samarasinghe, V., Kiribamune, S. \& Jayatilaka, V. (1990). Maternal Nutrition and Health Status of Indian Tamil Female Tea Plantation Workers in Sri Lanka. Maternal Nutrition and Health Care Program Report no. 8. Washington, DC: International Center for Research on Women.

Satyanarayana, K., Nadamuni Maidu, A. \& Narasinga Rao, B. S. (1978). Nutrition, physical work capacity and work output. Indian Joumal of Medical Research 68, Suppl., 88-93.

Scholl, T. O., Hediger, M. L. \& Ances, I. G. (1990). Maternal growth during pregnancy and decreased infant birth weight. American Journal of Clinical Nutrition 51, 790-793.

Schutz, Y., Lechtig, A. \& Bradfield, R. B. (1980). Energy expenditures and food intakes of lactating women in Guatemala. American Journal of Clinical Nutrition 33, 892-902.

Sennott-Miller, L. (1989). The health and socio-economic situation of mid-life and older women in Latin America and the Caribbean. Mid-Life and Older Women In Latin America and the Caribbean, pp. 1-125. Washington, DC: PAHO and American Association of Retired Persons.

Siega-Riz, A. M. \& Adair, L. S. (1993). Biological determinants of pregnancy weight gain in a Filipino population. American Joumal of Clinical Nutrition 57, 365-372.

Tripp, R. B. (1981). Farmers and traders: Some economic determinants of nutritional status in Northern Ghana. Journal of Tropical Pediatrics 27, 15-22.

Tucker, K. L. \& Lamba, C. (1990). Work Patterns, Parental Care and Nutritional Status of Pregnant Subsistence Farmers in Central Malawi. Maternal Nutrition and Health Care Program. Report no. 19. Washington, DC: International Center for Research on Women.

Ulijaszek, S. J., Hyndman, D. C., Lourie, J. A. \& Pumuye, A. (1987). Mining, modernisation and dietary change among the Wopkaimin of Papua New Guinea. Ecology of Food and Nutrition 20, 143-156.

United Nations International Children's Emergency Fund (1996). The State of the World's Children. New York: Oxford University Press.

University of the West Indies/Ministry of Health, Jamaica (1987). Report on a Survey of Iron Nutritional Status and Nutritional Anaemia in Jamaica. Kingston, Jamaica: University of the West Indies.

World Bank (1994). A New Agenda for Women's Health and Nutrition. Washington, DC: World Bank.

World Health Organization (1985). Energy and Protein Requirements. Technical Report Series no. 724. Geneva: WHO.

World Health Organization (1995). Physical Status: The Use and Interpretation of Anthropometry. Technical Report Series no. 854. Geneva: WHO. 